\title{
DEVELOPMENT OF MULTIMEDIA LEARNING SCIENCE FOR PRIMARY SCHOOLS BASED ON CONSTRUCTIVISTIC LEARNING THEORY
}

\author{
Nur Ngazizah, Titi Anjarini \\ Universitas Muhammadiyah Purworejo \\ ngazizah@umpwr.ac.id
}

Article History

accepted 30/09/2018

approved $12 / 10 / 2018$

published $30 / 10 / 2018$

\section{Keywords}

development, science, multimedia, contructivistic

\begin{abstract}
This study aims to develop learning multimedia that can be used in learning for fifth grade elementary school students. Multimedia development is aimed at blood competence. This research is a development research with a 4-D model (four $D$ model) proposed by Thiagarajan, which consists of four stages. The four stages are define, design, development and dissemination stages. disseminate). In the define stage, a curriculum review is conducted related to the competence of flat building. The results from the define phase are used as a reference for multimedia design. The next stage is design, at this stage has produced draft-1 results of the review and design in the previous stage. The next stage is development, at this stage draft I is validated by material experts and media experts. In general, material experts gave an assessment that multimedia draft $I$ was in accordance with KTSP and constructivistic learning theory. Media experts judge that multimedia is easy to use. The first draft was valid with revisions clarifying blood circulation construction, simplifying the start menu, adding quiz 1 , and adding motion animations at the beginning and end of the slide to make it more interesting. After the revised draft I developed into draft II to be tested in the classroom. Small scale 17 students in grade V SD N Purworejo Purworejo Regency. This trial is to find out the response of students. In this stage, an observation was also made by 1 teacher regarding the use of multimedia to complete the teacher's response questionnaire. The results of the teacher and student response questionnaire showed that 17 students were satisfied with multimedia draft II and students increasingly understood the blood flow system, circulatory structure, blood type and diseases of the blood. The revision towards draft III is the addition of applause as a tribute to students. As far as the stages of research have been carried out, it can be said that multimedia development can be used in the learning process and get positive responses from students. The next research phase is to conduct large-scale trials with more (two-class) research samples. The results of the trial will produce the final product which will then be disseminated (dessiminate stage).
\end{abstract}




\section{PENDAHULUAN}

Kualitas pendidikan di Indonesia yang diwakili oleh data dari TIMSS dan PISA juga menunjukkan peringkat Indonesia jauh dari kata menggembirakan. Hasil Trends in Mathematics and Science Study (TIMSS) yang diikuti siswa kelas VIII sebagaiana dikutip dari http://edukasi.kompas.com, prestasi matematika Indonesia di tahun 2011 berada di urutan ke-38 dengan skor 386 dari 42 negara. Skor Indonesia ini turun 11 poin dari penilaian tahun 2007. Prestasi bidang sains, Indonesia berada di urutan ke40 dengan skor 406 dari 42 negara. Skors tes sains siswa Indonesia ini turun 21 angka dibandingkan TIMSS 2007.

Melihat data yang ditampilkan di atas, maka dapat dikatakan bahwa pembelajaran yang terjadi di Indonesia sedikit banyak telah mangalami banyak permasalahan. Permasalahan utamanya adalah rendahnya prestasi belajar matematika. Rendahnya prestasi belajar sebagai salah satu indikator kualitas pendidikan harus segera dibenahi dengan berbagai cara.

Tantangan yang dihadapi dalam pendidikan dewasa ini adalah adanya kemajuan teknologi komputer.Oleh karena itu, dewasa ini banyak sekali pengembangan media pembelajaran berbasis komputer. Penggunaan komputer dalam proses pembelajaran dari berbagai hasil penelitian menyebutkan bahwa pembelajaran akan dapat berjalan lebih efektif dan siswa memunculkan antusias dan ketertarikan selama prose pembelajaran. Ketertarikan inilah yang menjadikan siswa dapat terus fokus mengikuti pembelajaran yang akhirnya mampu meningkatkan kemampuan dalam memahami dan menguasai konsep materi yang diajarkan.

Pandangan konstruktivistik telah mempengaruhi perkembangan multimedia interaktif. Pandangan konstruktivistik percaya bahwa metode pembelajaran tradisional seperti latihan dan praktik (drill and practice), kurang mampu mengembangkan pebelajar sepanjang hayat.Hal ini berarti metode belajar tersebut sulit untuk diterapkan pada situasi baru.Dalam pengembangan multimedia pembelajaran, teori konstruktivistik menganjurkan metode hypermedia, simulasi, dan lain-lain yang lebih bermanfaat bagi siswa. Dengan metode tersebut siswa bebas mencari informasi, menerapkan gaya belajar mereka sendiri, dan menggunakan perangkat lunak sebagai sumber belajar selain guru. Hal yang lebih penting lagi, menurut Jonassen (Allesi dan Trollip, 2001: 36) bahwa, teori konstruktivistik mendukung penggunaan computerbased tools, dimana siswa dapat merancang dan membangun sendiri pengetahuan mereka. Integrasi utama konstruktivistik dalam multimedia pembelajaran terletak pada interaktivitas.

Berdasarkan pada kedua hal tersebut di atas, yiatu penggunaan komputer dalam pembelajaran dan fakta adanya teori belajar kontruktivistik, maka penting diadakan suatu pengembangan produk multimedia yang didasarkan pada teori belajar kontruktivistik.

\section{METODE}

Penelitian ini termasuk penelitian pengembangan dan metode penelitian kuantitatif. Menurut Borg and Gall dalam Pusat Penelitian Kebijakan dan Inovasi Pendidikan, yang dimaksud dengan model penelitian dan pengembangan adalah " $a$ process used develop and validate educational product". Kadang- kadang penelitian ini juga disebut "research based development", yang muncul sebagai strategi dan bertujuan untuk meningkatkan kualitas pendidikan. Selain untuk mengembangkan dan memvalidasi hasil-hasil pendidikan, Research and Development juga bertujuan untuk menemukan pengetahuan-pengetahuan baru melalui "basic research", atau 
untuk menjawab pertanyaan-pertanyaan khusus tentang masalah-masalah yang bersifat praktis melalui "applied research", yang digunakan untuk meningkatkan praktik-praktik pendidikan. Penelitian pengembangan ini digunakan untuk mengembangkan multimedia pembelajaran sains berbasis teori belajar konstruktivistik.Sedangkan metode penelitian kuantitatif untuk melihat keterlaksanaan pembelajaran, respon siswa, serta hasil ketuntasan belajar siswa terhadap multimedia yang dikembangkan. Perangkat pembelajaran yang akan dikembangkan dalam penelitian ini adalah multimedia pembelajaran.

\section{HASIL DAN PEMBAHASAN}

\section{Tahap Define (Pendefinisian)}

Pada tahap ini dilakukan analisis kurikulum serta analisis kebutuhan guru dan siswa. Berdasarkan wawancara dengan dua orang guru kelas $V$ SD $N$ Purworejo, didapatkan bahwa kurikulum yang dipakai di SD N Purworejo adalah Kurikulum Tingkat Satuan Pendidikan (KTSP) untuk semua jenjang kelas I sampai VI. Materi yang ada di media pada sub bab materi darah, materi strktur darah disampaikan dalam bentuk animasi media

Diharapkan dari konstruksi struktur peredaran, siswa juga semakin paham pengertian, bagian-bagian darah, golongan darah dan penyakit yang timbul dari darah. Pemahaman ini akan nampak ketika siswa mengerjakan latihan soal, kuis 1, dan kuis 2 (tes prestasi).

Dari analisis kebutuhan guru dan siswa juga didapatkan bahwa guru dan siswa sudah terbiasa menggunakan media animasi. Karenanya untuk kemudahan penggunaan, multimedia yang dikembangkan adalah animasi. Mengingat bahwa komputer untuk tiap anak tidak tersedia di dalam kelas, tetapi hanya di laboratorium komputer, maka penggunaan media powerpointdikombinasikan dengan greenboard/papan tulis. Pengombinasian ini oleh guru juga mempermudah siswa dalam mengonstruksi sistem peredaraan darah.

\section{Tahap Design (Perancangan)}

Pada tahap ini dirancang multimedia dengan Macromedia Flash. Meskipun program ini sudah dikenal oleh guru dan siswa, akan tetapi penggunaannya belum optimal dan menarik. Agar optimal, program ini dirancang sesuai teori belajar konstruktivistik, yakni memancing siswa untuk membangun pemahaman mereka sendiri.Baik ketika siswa sendiri yang menjalankan program tersebut maupun ketika guru yang menjalankan program tersebut untuk mengarahkan siswa.

\section{Perancangan media pada tahap ini menghasilkan draft I}

\section{Tahap Development (Pengembangan)}

Pada tahap ini draft I mengalami tiga proses pengembangan sebagai berikut.

a. Validasi Ahli

Pada proses pertama, draft I divalidasi oleh ahli materi dan ahli media. Ahli materi adalah dosen pendidikan matematika, yakni Suyoto, M.Pd. Tabel 1 berikut adalah hasil angket validasinya.

Tabel 1. Hasil Angket Validasi Ahli Materi 
SHEs: Conference Series 1 (2) (2018) 334-339

\begin{tabular}{|c|l|c|}
\hline No. & \multicolumn{1}{|c|}{ Pernyataan } & Skor \\
\hline & \multicolumn{1}{|c|}{ Kualitas Materi } & \\
\hline 1 & Materi sesuai KTSP & 4 \\
\hline 2 & Keluasan cakupan isi materi & 5 \\
\hline 3 & Kejelasan isi materi & 4 \\
\hline 4 & Materi sesuai teori belajar konstruktivistik & 5 \\
\hline & \multicolumn{1}{|c|}{ Kualitas Bahasa } \\
\hline 5 & Kejelasan bahasa yang digunakan & 4 \\
\hline 6 & $\begin{array}{l}\text { Kesesuaian bahasa dengan sasaran } \\
\text { pengguna }\end{array}$ & 4 \\
\hline & \multicolumn{1}{|c|}{ Kualitas Latihan Soal dan Kuis } \\
\hline 7 & $\begin{array}{l}\text { Kesesuaian latihan soal dan kuis dengan } \\
\text { kompetensi }\end{array}$ & 5 \\
\hline 8 & Runtutan penyajian latihan soal dan kuis & 5 \\
\hline 9 & $\begin{array}{l}\text { Latihan soal sesuai teori belajar } \\
\text { konstruktivistik }\end{array}$ & 5 \\
\hline 10 & Kunci jawaban dan penskoran & 4 \\
\hline \multicolumn{1}{|c|}{ TOTAL SKOR } & $\mathbf{4 5}$ \\
\hline
\end{tabular}

Dari total skor 45 maka multimedia dinyatakan valid oleh ahli materi. Sedangkan ahli media adalah dosen media pembelajaran, yakni Drs. Lilik Wahyu Utomo, M. Pd. Tabel 2 berikut adalah hasil angket validasinya.

Tabel 2. Hasil Angket Validasi Ahli Media

\begin{tabular}{|c|c|c|}
\hline No & Pernyataan & Skor \\
\hline & Kualitas Grafis & \\
\hline 1 & Tata letak teks dan gambar & 4 \\
\hline 2 & Kesesuaian pemilihan background & 4 \\
\hline 3 & Kesesuaian pemilihan ukuran dan jenis huruf & 4 \\
\hline 4 & Kesesuaian warna & 4 \\
\hline 5 & Kemenarikan sajian gambar animasi & 3 \\
\hline 6 & $\begin{array}{l}\text { Kesesuaian pemilihan gambar animasi dengan } \\
\text { materi }\end{array}$ & 4 \\
\hline \multirow[t]{2}{*}{7} & $\begin{array}{l}\text { Kesesuaian balon kata dengan teori belajar } \\
\text { konstruktivistik }\end{array}$ & 5 \\
\hline & Kualitas Tombol & \\
\hline 8 & Kemenarikan tampilan tombol & 4 \\
\hline \multirow[t]{2}{*}{9} & Keteraturan dan konsistensi tampilan tombol & 4 \\
\hline & Efisiensi Media & \\
\hline 10 & Kemudahan pemakaian program & 5 \\
\hline 11 & Kemudahan memilih menu program & 5 \\
\hline 12 & $\begin{array}{l}\text { Kemudahan berinteraksi dengan program } \\
\text { sesuai teori belajar konstruktivistik }\end{array}$ & 5 \\
\hline \multirow[t]{2}{*}{13} & Kemudahan masuk dan keluar dari program & 5 \\
\hline & Fungsi Tombol & \\
\hline 14 & Kemudahan memahami struktur tombol & 5 \\
\hline \multirow[t]{2}{*}{15} & Ketepatan reaksi tombol & 5 \\
\hline & Kualitas Fisik & \\
\hline 16 & $\begin{array}{l}\text { Kapasitas file program untuk kemudahan } \\
\text { duplikasi/penggandaan }\end{array}$ & 5 \\
\hline \multirow[t]{2}{*}{17} & Kekuatan/keawetan program & 5 \\
\hline & TOTAL SKOR & 76 \\
\hline
\end{tabular}

Dari total skor 76 maka multimedia dinyatakan valid oleh ahli media. Setelah proses revisi di atas, multimedia berkembang menjadi draft II yang diujicobakan pada skala kecil. Berikut penjelasannya

b. Uji Coba Skala Kecil

Pada proses pengembangan yang kedua ini, draft II diujicobakan pada 17 siswa kelas $\mathrm{V}$. Uji coba ini adalah untuk mengetahui respon siswa (Tabel 5). Proses uji coba diamati oleh 1 orang guru untuk dilakukan pengisian angket respon guru (Tabel 3) 
Tabel 3. Hasil Angket Respon Siswa

\begin{tabular}{|l|l|c|}
\hline No & \multicolumn{1}{|c|}{ Pernyataan } & Skor \\
\hline 1 & Guru menggunakan media yang menarik & 3 \\
\hline 2 & $\begin{array}{l}\text { Apakah saya berhasil / tidak berhasil dalam } \\
\text { pembelajaran ini, hal itu tergantung pada saya }\end{array}$ & 2.7 \\
\hline 3 & Saya sering melamun di kelas & 2.5 \\
\hline 5 & $\begin{array}{l}\text { Guru membuat suasana menjadi tegang apabila } \\
\text { mengajarkan materi }\end{array}$ & 2.8 \\
\hline 6 & $\begin{array}{l}\text { Saya merasa memperoleh cukup penghargaan } \\
\text { dalam bentuk nilai, komentar, atau masukan lain }\end{array}$ & 2.3 \\
\hline 7 & Saya merasa kecewa dengan pembelajaran ini & 2.8 \\
\hline 8 & $\begin{array}{l}\text { Saya yakin bahwa saya akan berhasil dalam } \\
\text { pembelajaran ini }\end{array}$ & 2.7 \\
\hline 9 & Saya senang bekerja dalam pembelajaran ini & 2.6 \\
\hline 10 & $\begin{array}{l}\text { Media yang dipakai dalam pembelajaran ini tidak } \\
\text { bermanfaat bagi saya }\end{array}$ & 3 \\
\hline 11 & $\begin{array}{l}\text { Menggunakan media seperti ini membuat saya tidak } \\
\text { mengerti materi pembelajaran }\end{array}$ & 2.8 \\
\hline 12 & $\begin{array}{l}\text { Media yang digunakan membuat saya menjadi bosan } \\
\text { belajar }\end{array}$ & 2.9 \\
\hline & \multicolumn{1}{|c|}{ TOTAL SKOR } \\
\hline
\end{tabular}

Tabel 4. Hasil Angket Respon Guru

\begin{tabular}{|c|c|c|}
\hline No. & Pernyataan & Skor \\
\hline & Aspek Pemrograman & \\
\hline 1 & Kemudahan pemakaian media & 5 \\
\hline 2 & Kemudahan memilih menu program & 5 \\
\hline 3 & Kemudahan masuk dan keluar dari program & 5 \\
\hline \multirow[t]{2}{*}{4} & Ketepatan reaksi tombol & 5 \\
\hline & Aspek Isi & \\
\hline 5 & Tidak ada kata/kalimat yang negatif & 5 \\
\hline 6 & $\begin{array}{l}\text { Latihan soal dan kuis sesuai dengan materi } \\
\text { yang disampaikan }\end{array}$ & 5 \\
\hline 7 & $\begin{array}{l}\text { Melalui media ini siswa mudah memahami } \\
\text { materi pembelajaran }\end{array}$ & 4 \\
\hline 8 & $\begin{array}{l}\text { Penyajian materi dan balon kata sesuai teori } \\
\text { belajar konstruktivistik }\end{array}$ & 5 \\
\hline 9 & $\begin{array}{l}\text { Latihan soal jelas dan sesuai dengan teori } \\
\text { belajar konstruktivistik }\end{array}$ & 5 \\
\hline 10 & $\begin{array}{l}\text { Bahasa yang digunakan mudah dipahami dan } \\
\text { komunikatif }\end{array}$ & 4 \\
\hline 11 & $\begin{array}{l}\text { Latihan soal dan kuis yang diberikan sesuai } \\
\text { dengan kemampuan siswa }\end{array}$ & 5 \\
\hline \multirow[t]{2}{*}{12} & $\begin{array}{l}\text { Soal kuis } 2 \text { adalah pengembangan konstruksi } \\
\text { pemahaman siswa tentang luas bangun datar }\end{array}$ & 4 \\
\hline & Aspek Tampilan & \\
\hline 13 & Tata letak teks dan gambar & 4 \\
\hline 14 & Kesesuaian pemilihan background & 4 \\
\hline 15 & Kesesuaian warna & 4 \\
\hline 16 & Kesesuaian pemilihan ukuran dan jenis huruf & 4 \\
\hline 17 & Kesesuaian gambar animasi yang disajikan & 5 \\
\hline 18 & $\begin{array}{l}\text { Kemenarikan tampilan tombol yang } \\
\text { digunakan }\end{array}$ & 4 \\
\hline 19 & $\begin{array}{l}\text { Kemenarikan gambar animasi yang } \\
\text { digunakan }\end{array}$ & 4 \\
\hline & TOTAL SKOR & 86 \\
\hline
\end{tabular}

Karena total skor angket respon siswa adalah 33.1 serta total skor angket respon guru adalah 86, maka draft II dapat dikembangkan menjadi draft III. Pengembangan draft II berdasarkan catatan lapangan peneliti yakni dengan menambah suara tepuk tangan di Macromedia Flash sebagai bentuk penghargaan kepada siswa. Hal ini sekaligus untuk memperbaiki skor pernyataan 5 pada angket respon siswa. 
Berdasarkan tahapan penelitian yang telah dilakukan sejauh ini, pengembangan multimedia pembelajaran dapat dilakukan melalui pemanfaatan Macromedia Flash yang penggunaanya sudah dikenal secara luas oleh guru. Dengan kata lain, multimedia ini dapat digunakan sebagai media bantu proses pembelajaran sains materi darah. Hasil masukan dari para validator dan hasil observasi menunjukkan sinyal positif bahwa media ini sudah layak untuk digunakan.

Guru harus terus meningkatkan kemampuan sehingga mampu meghasilkan produk multimedia pembelajaran untuk materi yang lain. Pemuatan multimedia ini harus didasarkan pada karakter konsep materi yang akan diajarkan, sedapat mungkin guru harus merancang multimedianya sehingga timbul interaksi antara siswa dengan media yang digunakan.

\section{DAFTAR PUSTAKA}

Allesi, S. M. danTrollip, A. R. (2001).Multimedia for learning: Methods and development. Massachusetts, America: Allyn and Bacon.

Arief S. Sadiman. (2003). Media pendidikan. Jakarta: PT. Raja Grafindo Persada.

Asri Budiningsih. C. (2003). Desain pesan pembelajaran. Yogyakarta: Fakultas IImu Pendidikan. Universitas Negeri Yogyakarta.

Borg, Walter R. \& Gall, Meredith D. (1983). Educational research. An introduction (4 ed). New York \&London : Longman.

Budiyono.2000. Statistika Dasar Untuk Penelitian. Surakarta: UNS Press.

Heinich, Molenda, Russel, \& Smaldino.(1996). Instructional media and technologies for learning.New Jersey: Printice-Hall, Inc. A Simon \& Schuster Company.

Phillips, Rob. (1997). The developer's handbook to interactive multimedia (A practical guide for educational appications).London: Kogan Page.

Sutirman.Multimedia Pembelajaran.Diambil dari http://tirman.wordpress.com/ multimedia-pembelajaran/ Pada Minggu, 28 Mei 2016.

Uwes Chaeruman. (2008). Tips Membuat Media Presentasi dengan MS Power Point. Handout 